\title{
ß-Oxidation Enzymes in Fibroblasts from Patients with 3-Hydroxydicarboxylic Aciduria
}

\author{
NIKOLAOS VENIZELOS, LODEWIJK IJLST, RONALD J. A. WANDERS, AND \\ LARS HAGENFELDT \\ Department of Clinical Chemistry, Karolinska Institute, Huddinge University Hospital, S-141 86 \\ Huddinge, Sweden [N.V., L.H.], and Department of Clinical Biochemistry and Paediatrics, \\ University Hospital Amsterdam, 1105 AZ Amsterdam, The Netherlands [L.I., R.J.A.W.]
}

\section{ABSTRACT}

The activities of 3-hydroxyacyl-CoA dehydrogenase, enoyl-CoA hydratase, and 3-ketoacyl-CoA thiolase were measured in fibroblasts from eight patients with 3-hydroxydicarboxylic aciduria. Measurement of 3-hydroxyacyl-CoA dehydrogenase with 3-ketopalmitoyl-CoA as substrate provided conclusive evidence for a deficiency of the longchain 3-hydroxyacyl-CoA dehydrogenase in seven of the patients. Measurement of the enzyme in the normal direction cannot be recommended because this gives a higher residual activity. A trifunctional enzyme protein is respon-

In recent years, an increasing number of inherited diseases in humans in which there is an impairment in mitochondrial $\beta$-oxidation have been recognized $(1,2)$. Defects of several enzymes of $\beta$-oxidation such as the long-chain, medium-chain, and short-chain acyl-CoA dehydrogenases have been described $(1,2)$. Recent studies on 3-hydroxydicarboxylic aciduria showed that many but not all of the patients who are characterized by the massive excretion of 3-hydroxydicarboxylic acids have deficient activity of the mitochondrial LCHAD (3-12). Moreover, LCHAD seems to be associated with a trifunctional enzyme having also enoyl-CoA hydratase and 3-ketoacyl-CoA thiolase activity (13-15).

Previously, we have reported clinical data on five children with 3-hydroxydicarboxylic aciduria with a suspected defect in mitochondrial $\beta$-oxidation, possibly at the level of the 3-hydroxyacyl-CoA dehydrogenase (4). The clinical features described in these patients include hypoglycemia, myopathy, cardiomyopathy, fatty infiltration of the liver, peripheral neuropathy, and pigmentary retinopathy (3-12). In this report, assays of 3-hydroxyacyl-CoA dehydrogenase, enoyl-CoA hy-

Received April 22, 1993; accepted January 21, 1994.

Correspondence: Nikolaos Venizelos, Karolinska Institute, Department of Clinical Chemistry, Huddinge University Hospital, S-141 86 Huddinge, Sweden

Supported by grants from the Swedish Medical Research Council (722) and the Karolinska Institute. sible for the 3-hydroxyacyl-CoA dehydrogenase as well as for the hydratase and thiolase activities. A slight decrease in one or both of the other two activities was observed in four of the seven deficient patients, indicating that a defect in the trifunctional enzyme protein may affect the three enzyme activities to different degrees. (Pediatr Res 36: 111-114, 1994)

\section{Abbreviations}

LCHAD, long-chain 3-hydroxyacyl-CoA dehydrogenase

dratase, and 3-ketoacyl-CoA thiolase activities in cultured fibroblast provide conclusive evidence for a deficient activity of LCHAD in four of the five reported cases and in three additional new cases of 3-hydroxydicarboxylic aciduria. Similarly, in four of the seven patients with LCHAD deficiency, we observed slight decreases in enoyl-CoA hydratase or 3-ketoacyl-CoA thiolase activities.

\section{METHODS}

Subjects. Skin biopsies were obtained from eight patients with defects in the oxidative metabolism of fatty acids, three males (patients 1, 6, and 8) and five females (patients 2, 3, 4, 5, and 7). All patients had 3-hydroxydicarboxylic aciduria, and clinical data on five patients (patients 1 through 5) have been published earlier (4). Four of these patients died between the 4th and 16th mo of age because of liver failure and cardiomyopathy. The remaining four patients (patients 5 through 8 ) are still alive. Clinical data for the last three patients will be published elsewhere.

Chemicals and culture media. All growth media and antibiotics were obtained from Gibco BRL (Life Technologies, European Division), and enzymes were obtained from Boehringer Mannheim GmbH (Mannheim, Germany). Acyl-CoA and other chemicals were purchased from Sigma (St. Louis, MO). The 3-ketoacyl-CoA 
and 2-enoyl-CoA esters were synthesized enzymatically (as detailed below).

Cell culture. Fibroblasts were cultured from skin biopsies using Eagle's minimum essential medium containing FCS $(10 \%, \mathrm{vol} / \mathrm{vol})$, penicillin $(125 \mathrm{IU} / \mathrm{mL})$, streptomycin $(125 \mu \mathrm{g} / \mathrm{mL})$, and Tylocine [ $6 \mathrm{mg} / \mathrm{mL}$ (anti-PPLO agent); Gibco BRL]. Stock cultures of individual fibroblast strains were cultured in $75-\mathrm{cm}^{2}$ plastic tissue culture flasks in a humidified atmosphere of $5 \% \mathrm{CO}_{2}$ in air at $37^{\circ} \mathrm{C}$. Fibroblast lines were used between the 8 th and 16 th passage. The cells were frequently checked for mycoplasma and bacterial contamination.

Preparation of 3-ketoacyl-CoA and 2-enoyl-CoA. The 3-ketooctanoyl-CoA, 3-ketolauroyl-CoA, and 3-ketopalmitoyl-CoA substrates were synthesized enzymatically from octanoyl-CoA, lauroyl-CoA, and palmitoylCoA by using commercially available acyl-CoA oxidase, crotonase, and 3-hydroxyacyl-CoA dehydrogenase and purified as described elsewhere (16).

Enzyme assays. The activity of 3-hydroxyacyl-CoA dehydrogenase in fibroblast homogenates was measured in the "reverse" direction as described by Wanders et al. (5). The assay mixture contained $50 \mathrm{mmol} / \mathrm{L} 2-(\mathrm{N}$ morpholino)ethanesulfonic acid, $100 \mathrm{mmol} / \mathrm{L}$ potassium phosphate, $0.1 \%$ (wt/vol) Triton X-100, $100 \mu \mathrm{mol} / \mathrm{L}$ $\mathrm{NADH}$ (final $\mathrm{pH}=6.16$ ), and fibroblast homogenate. Reactions were started by adding 3-oxoacyl-CoA ester at a final concentration of $50 \mu \mathrm{mol} / \mathrm{L}$ for acetoacetyl-CoA (C4) and $40 \mu \mathrm{mol} / \mathrm{L}$ for 3-keto-palmitoyl-CoA (C16).

The 3-hydroxyacyl-CoA-dependent $\mathrm{NAD}^{+}$reduction (forward reaction) was assayed with enoyl-CoA as substrate in the presence of crotonase (17). A solution containing $0.1 \mathrm{~mol} / \mathrm{L}$ Tris- $\mathrm{KCl}(\mathrm{pH} 10.2), 0.6 \mathrm{IU} / \mathrm{mL}$ crotonase, and $50 \mu \mathrm{mol} / \mathrm{L} 2$-enoyl-CoA in a total volume of 0.8 $\mathrm{mL}$ was incubated for $3 \mathrm{~min}$. Cell homogenate was then added, the reaction was started by adding $1 \mathrm{mmol} / \mathrm{L}$ $\mathrm{NAD}^{+}$, and the increase in absorbance at $340 \mathrm{~nm}$ was followed.

The short-chain 3-ketothiolase activity was measured at $37^{\circ} \mathrm{C}$ in homogenates of cultured skin fibroblasts by following the decrease in absorbance at $303 \mathrm{~nm}$ using a medium containing $100 \mathrm{mmol} / \mathrm{L}$ Tris- $\mathrm{HCl}(\mathrm{pH} \mathrm{8.05}), 10$ $\mathrm{mmol} / \mathrm{L} \mathrm{MgCl}_{2}, 50 \mathrm{mmol} / \mathrm{L} \mathrm{KCl}$ (if added), $50 \mu \mathrm{mol} / \mathrm{L}$ $\mathrm{CoA}, 50 \mu \mathrm{mol} / \mathrm{L}$ acetoacetyl-CoA, and $0.1 \%$ (wt/vol) Triton X-100 (5).

The long-chain 3-ketothiolase activity was determined in the presence of $25 \mathrm{mmol} / \mathrm{L} \mathrm{MgCl}, 75 \mu \mathrm{mol} / \mathrm{L} \mathrm{CoA}, 10$ $\mu \mathrm{mol} / \mathrm{L} 3$-ketohexadecanoyl-CoA, and $0.2 \mathrm{mg} / \mathrm{mL}$ BSA. Reactions were started after preincubation for $2 \mathrm{~min}$ by adding CoA.

The enoyl-CoA hydratase activity was measured at $37^{\circ} \mathrm{C}$ by following the increase in absorbance at $365 \mathrm{~nm}$. A solution containing $100 \mathrm{mmol} / \mathrm{L}$ Tris- $\mathrm{HCl}(\mathrm{pH} 8.0)$, $0.1 \%$ (wt/vol) Triton X-100, $1 \mathrm{mmol} / \mathrm{L}$ 3-acetylpyridine adenine dinucleotide, $7.1 \mathrm{IU} / \mathrm{mL}$ 3-hydroxyacyl-CoA dehydrogenase, and fibroblast homogenate was preincubated for $2 \mathrm{~min}$. The reaction was then started by adding $0.1 \mathrm{mmol} / \mathrm{L}$ substrate (2-enoyl-CoA) (16).

\section{RESULTS}

The third reaction of $\beta$-oxidation is the reversible dehydrogenation of 3-hydroxyacyl-CoA to 3-ketoacyl-CoA catalyzed by 3-hydroxyacyl-CoA dehydrogenase. In the present study, the activity of this enzyme was determined in both directions. In the reverse reaction, 3-oxoacylCoA with chain lengths of four, eight, and 16 carbon atoms were used as substrates. The results (Table 1) show that fibroblasts from seven of eight patients with 3-hydroxydicarboxylic aciduria had strongly reduced activities when the $C_{16}$ substrate was used $(11 \pm 2$ compared with $50 \pm 6 \mathrm{nmol} / \mathrm{min} / \mathrm{mg}$ protein for the controls). The average residual activity was $22 \%$ of the control mean. The decrease was less pronounced with $\mathrm{C}_{8}$ substrate (59\% of control mean), and the activity was normal with $\mathrm{C}_{4}$. Similar results were obtained when 3-hydroxyacyl-CoA dehydrogenase was measured in the forward direction using 3-hydroxybutyryl-CoA $\left(\mathrm{C}_{4}\right)$, 3-hydroxylauryl-CoA $\left(\mathrm{C}_{12}\right)$, and 3-hydroxypalmitoyl-CoA $\left(\mathrm{C}_{16}\right)$ as substrates (Table 1). The activities measured with the forward assay were generally lower than those of the reverse assay. The differences between patients and controls were also less pronounced with the forward assay. The $\mathrm{C}_{16}$ activity in the patients was, on the average, decreased to $48 \%$ of the mean of controls when measured in the forward direction.

With long-chain substrates, the activities were also decreased to slightly below the control mean minus $2 \mathrm{SD}$ for the enoyl-CoA hydratase in three patients (patients 3 , 4, and 8) and for 3-ketothiolase in three patients (patients 3,4 , and 7; Tables 2 and 3). Addition of activator (50 $\mathrm{mmol} / \mathrm{L} \mathrm{KCl}$ ) caused an increase in the activity of shortchain 3-ketothiolase to a similar extent in both patients and controls ( 81 and $89 \%$, respectively).

Table 1. 3-Hydroxyacyl-CoA dehydrogenase activity determined in forward and reverse directions in cultured skin fibroblasts from 3-hydroxydicarboxylic aciduria patients and controls*

\begin{tabular}{|c|c|c|c|c|}
\hline & \multicolumn{2}{|c|}{ Forward } & \multicolumn{2}{|c|}{ Reverse } \\
\hline & $\mathrm{C} 4$ & $\mathrm{C} 16$ & $\mathrm{C} 4$ & $\mathrm{C} 16$ \\
\hline $\begin{array}{l}\text { Controls, } n=5 \\
\quad(\text { mean } \pm \mathrm{SD})\end{array}$ & $16.5 \pm 2.4$ & $12.5 \pm 1.7$ & $54 \pm 10$ & $50 \pm 6$ \\
\hline \multicolumn{5}{|l|}{ Patient } \\
\hline 1 & 16.9 & $7.0(56)$ & 41 & $12.0(24)$ \\
\hline 2 & 17.2 & $5.6(45)$ & 83 & $15.6(31)$ \\
\hline 3 & 13.5 & $5.5(44)$ & 43 & $11.0(22)$ \\
\hline 4 & 12.5 & $5.3(42)$ & 41 & $9.1(18)$ \\
\hline 6 & 16.0 & $5.8(46)$ & 46 & $10.5(21)$ \\
\hline 7 & 17.3 & $7.2(58)$ & 47 & $11.5(23)$ \\
\hline 8 & 12.9 & $5.5(44)$ & 37 & $9.6(19)$ \\
\hline Mean \pm SD & $15 \pm 2$ & $6.0 \pm 0.8$ & $48 \pm 16$ & $11 \pm 2$ \\
\hline Patient 5 & 19.6 & $13.2(106)$ & 62 & $47.0(94)$ \\
\hline
\end{tabular}

* Enzyme activity rates are given in $\mathrm{nmol} \cdot \mathrm{min}^{-1} \cdot(\mathrm{mg} \text { protein })^{-1}$ with 3-hydroxybutyryl-CoA (C4) and 3-hydroxypalmitoyl-CoA (C16) as substrates for the forward and acetoacetyl-CoA (C4) and 3-ketopalmitoyl-CoA $(\mathrm{C16})$ for the reverse. Percent of the mean of controls in parentheses. 
Table 2. Enoyl-CoA hydratase activity in cultured skin fibroblasts from 3-hydrohydicarboxylic aciduria patients and controls*

\begin{tabular}{lcc}
\hline & $\mathrm{C} 4$ & $\mathrm{C} 12$ \\
\hline Controls, $n=5$ (mean \pm SD) & $265 \pm 67$ & $56 \pm 7$ \\
$\begin{array}{l}\text { Patient } \\
1\end{array}$ & 290 & $45.5(81)$ \\
2 & 367 & $53.5(96)$ \\
3 & 220 & $40.5(72)$ \\
4 & 210 & $35.1(63)$ \\
6 & 293 & $53.9(96)$ \\
7 & 251 & $46.1(82)$ \\
8 & 224 & $39.0(70)$ \\
Mean \pm SD & $265 \pm 56$ & $45 \pm 7$ \\
Patient 5 & 255 & $50(89)$ \\
\hline
\end{tabular}

* Enzyme activity rates are given in $\mathrm{nmol} \cdot \mathrm{min}^{-1} \cdot(\mathrm{mg} \text { protein })^{-1}$ with 2-enoyl-CoA ( $\mathrm{C} 4: 1$ and $\mathrm{C12:1})$ as substrates. Percent of the mean of controls in parentheses.

Table 3. 3-Ketoacyl-CoA thiolase activity in cultured skin fibroblasts from 3-hydroxydicarboxylic aciduria patients and controls*

\begin{tabular}{lcccc}
\hline & $\mathrm{C} 4-\mathrm{K}^{+}$ & $\mathrm{C} 4+\mathrm{K}^{+}$ & $\begin{array}{c}\mathrm{C} 4+\mathrm{K}^{+} /-\mathrm{K}^{+} \\
\text {ratio }\end{array}$ & $\mathrm{C} 16$ \\
\hline Controls & $n=16$ & $n=16$ & & $n=7$ \\
(mean $\pm \mathrm{SD})$ & $6.4 \pm 1.8$ & $12.1 \pm 4.0$ & $1.9 \pm 0.6$ & $4.9 \pm 0.5$ \\
Patient & & & & \\
$\quad 1$ & 7.0 & 12.8 & $1.8(95)$ & $4.7(96)$ \\
2 & 12.8 & 23.6 & $1.8(95)$ & $4.0(82)$ \\
3 & 5.1 & 9.0 & $1.8(95)$ & $3.6(73)$ \\
4 & 6.0 & 9.1 & $1.5(79)$ & $3.3(67)$ \\
6 & 5.3 & 10.0 & $1.9(100)$ & $4.0(82)$ \\
7 & 2.4 & 4.8 & $2.0(105)$ & $3.2(65)$ \\
8 & 5.0 & 8.9 & $1.8(95)$ & $4.0(82)$ \\
Mean \pm SD & $6.2 \pm 3.2$ & $11.2 \pm 6.0$ & $1.8 \pm 0.2$ & $3.8 \pm 0.5$ \\
Patient 5 & 9.3 & 15.4 & $1.7(89)$ & $4.4(90)$ \\
\hline
\end{tabular}

* Enzyme activity rates are given in $\mathrm{nmol} \cdot \mathrm{min}^{-1} \cdot(\mathrm{mg} \text { protein })^{-1}$ with acetoacetyl-CoA with $50 \mathrm{mmol} / \mathrm{L} \mathrm{K} \mathrm{K}^{+}\left(\mathrm{C}_{4}+\mathrm{K}^{+}\right)$, 3-acetoacetyl$\mathrm{CoA}$ without $50 \mathrm{mmol} / \mathrm{L} \mathrm{K}^{+}\left(\mathrm{C} 4_{-}-\mathrm{K}^{+}\right)$, and 3-ketohexadecanoyl-CoA (C16) as substrates. Percent of the mean of controls in parentheses.

\section{DISCUSSION}

We have previously described five patients with 3-hydroxydicarboxylic aciduria with early onset of hypoketotic hypoglycemia. Four of the patients died at the age of 4-16 mo with fat infiltration in liver and heart (4). Three additional patients with similar clinical presentation have since been observed. The characteristic biochemical findings of a massive excretion of 3-hydroxydicarboxylic acids in the urine and the accumulation of 3-hydroxy fatty acids in serum during acute illness in the patients led us to suspect a defect in mitochondrial $\beta$-oxidation. Our previous results (4) showed that the metabolic defect was not at the level of the acyl-CoA dehydrogenases.

We have now shown that four of these patients had a deficiency of LCHAD. The patient with normal LCHAD activity (patient 5 in ref. 4) had a urinary excretion pattern similar to that of the other patients with 3-hydroxydicarboxylic aciduria. The clinical presentation was, however, somewhat different. She was the only of the five original patients that survived into childhood (she is still alive). She also had more severe neurologic symp- toms than the others (abnormal EEG, seizures, transient hemiparesis). Moreover, the rate of palmitate oxidation in intact fibroblasts from this patient was in the low normal range (unpublished data). This girl may have a respiratory chain defect, but it has not been possible to make any further investigations regarding this. The findings in this girl demonstrate that 3-hydroxydicarboxylic aciduria may be caused by conditions other than LCHAD deficiency.

In the present study, the activities of 3-hydroxyacylCoA dehydrogenase in homogenates of cultured fibroblasts were assayed in both directions (forward and reverse) using substrates of different chain lengths. A considerable rest activity was observed in fibroblasts from the deficient patients with $\mathrm{C}_{16}$ substrates, accounting for $22 \%$ in the reverse and $48 \%$ in the forward reaction. There are several possible sources for this remaining LCHAD activity. First, the assays were performed in total homogenates of fibroblasts, and activities from the genetically separate peroxisomal $\beta$-oxidation enzymes may have been included. Recent immunoprecipitation studies by Jackson et al. (18) suggest that the high level of residual activity is almost completely caused by shortchain 3-hydroxyacyl-CoA dehydrogenase, which also reacts with the C16 substrate. Recent gel filtration experiments (16) support this notion.

The mitochondrial, membrane-bound LCHAD activity in both rat (14) and human (15) liver is associated with a trifunctional enzyme having also enoyl-CoA hydratase and 3-ketoacyl-CoA thiolase activity. The enzyme is composed of two nonidentical subunits in both species. Comparing the ratios between the three activities measured in the purified enzyme (15) with the ratios observed in control fibroblasts in the present study, it appears possible that this trifunctional enzyme is responsible for a major part of all three activities that we have measured with long-chain substrates. Inasmuch as the enzyme is a heterotetramer, it is conceivable that different mutations could affect the three separate activities to different degrees. The slight decrease in enoyl-CoA hydratase and 3-ketoacyl-CoA thiolase activities observed in some of our patients could be explained in this way. Inasmuch as the patients were selected because they excreted 3-hydroxydicarboxylic acids, it is not surprising that the 3-hydroxyacyl-CoA dehydrogenase activity was the most severely affected in all of them.

\section{REFERENCES}

1. Vianey-Liand C, Divry P, Gregersen N, Mathieu M 1987 The inborn errors of mitochondrial fatty acid oxidation. J Inherit Metab Dis 10(suppl 1):159-198

2. Pollitt RJ 1989 Disorders of mitochondrial $\beta$-oxidation: prenatal and early postnatal diagnosis and their relevance to Reye's syndrome and sudden infant death. J Inherit Metab Dis 12(suppl 1):215-230

3. Pollitt RJ, Losty H, Westwood A 1987 3-Hydroxydicarboxylic aciduria: a distinctive type of intermittent dicarboxylic aciduria of possible diagnostic significance. J Inherit Metab Dis 2:266-269

4. Hagenfeldt L, von Döbeln U, Holme E, Alm J, Brandberg G, Enocksson E, Lindberg L 1990 3-Hydroxydicarboxylic aciduria: a fatty acid oxidation defect with severe prognosis. J Pediatr 116:387-392

5. Wanders RJA, Ijlst L, van Gennip AH, Jakobs C, de Jager JP, Dorland L, van Sprang FJ, Duran M 1990 Long-chain 3-hydroxyacyl-CoA dehydrogenase 
deficiency: identification of a new inborn error of mitochondrial fatty acid B-oxidation. J Inherit Metab Dis 13:311-314

6. Rocchiccioli F, Wanders RJA, Aubourg P, Vianey-Liaud C, Ijlst L, Fabre M, Cartier N, Bougnères PF 1990 Deficiency of long-chain 3-hydroxyacyl-CoA dehydrogenase: a cause of lethal myopathy and cardiomyopathy in early childhood. Pediatr Res 28:657-662

7. Duran M, Wanders RJA, de Jager JP, Dorland L, Bruinvis L, Ketting D, Ijlst L, van Sprang L 1991 3-hydroxydicarboxylic aciduria due to long-chain 3-hydroxyacyl-CoA deficiency associated with sudden neonatal death. Protective effect of medium-chain triglyceride treatment. Eur J Pediatr 150:190195

8. Dionisi-Vici C, Burlina AB, Bertini E, Hale DE, Bachmann C, Mazziotta MRM, Zacchello F, Sabetta G, Hale DE 1991 Progressive neuropathy and recurrent myoglobinuria in a child with long-chain 3-hydroxyacyl-CoA dehydrogenase deficiency. J Pediatr 118:744-746

9. Wanders RJA, Ijlst L, Duran M, Jakobs $C$, de Klerk JBC, Przyrembel $H$, Rocchiccoili F, Aubourg P 1991 Long-chain 3-hydroxyacyl-CoA dehydrogenase deficiency: different clinical expression in three unrelated patients. $J$ Inherit Metab Dis 14:325-328

10. Przyrembel H, Jakobs C, Ijlst L, de Klerk JBC, Wanders RJA 1991 Longchain 3-hydroxyacyl-CoA dehydrogenase deficiency. J Inherit Metab Dis $14: 674-680$

11. Bertini E, Dionisi-Vici C, Garavaglia B, Burlina AB, Sabatelli M, Rimoldi M, Bartuli A, Sabetta G, DiDonato S 1992 Peripheral sensory-motor polyneuropathy, pigmentary retinopathy, and fatal cardiomyopathy in long- chain 3-hydroxyacyl-CoA dehydrogenase deficiency. Eur J Pediatr 151:121-126

12. Olpin SE, Manning NJ, Carpenter K, Middleton B, Pollitt RJ 1992 Differential diagnosis of hydroxydicarboxylic aciduria based on release of ${ }^{3} \mathrm{H}_{2} \mathrm{O}$ from $\left[9,10-{ }^{3} \mathrm{H}\right]$ palmitic acids by intact cultured fibroblasts. J Inherit Metab Dis 15:883-890

13. Carpenter K, Middleton B, Pollitt RJ 1991 The long-chain 3-hydroxyacyl-CoA dehydrogenase of human liver mitochondria. J Inherit Metab Dis 14:321-324

14. Uchidat Y, Izai K, Orii T, Hasimoto T 1992 Novel fatty acid $\beta$-oxidation enzymes in rat liver mitochondria. II. Purification and properties of enoylCoA hydratase/3-hydroxyacyl-CoA dehydrogenase/3-ketoacyl-CoA thiolase trifunctional protein. J Biol Chem 267:1034-1041

15. Carpenter K, Pollitt RJ, Middleton B 1992 Human liver long-chain 3-hydroxyacyl-CoA dehydrogenase is a multifunctional membrane-bound betaoxidation enzyme of mitochondria. Biochem Biophys Res Commun 183:443-448

16. Wanders RJA, Ijlst L, Pogi F, Bonnefont JP, Munnich A, Brivet M, Rabier $D$, Saudubray JM 1992 Human trifunctional protein deficiency: a new disorder of mitochondrial fatty acid $\beta$-oxidation. Biochem Biophys Res Commun 188: 1139-1145

17. Osumi T, Hashimoto T 1980 Purification and properties of mitochondrial and peroxisomal 3-hydroxyacyl-CoA dehydrogenase from rat liver. Arch Biochem Biophys 203:372-383

18. Jackson S, Bartlett K, Land J, Moxon ER, Pollit RJ, Leonard JV, Turnbull DM 1991 Long-chain 3-hydroxyacyl-CoA dehydrogenase deficiency. Pediatr Res 29:406-411 